\title{
INVESTIGATING THE ROLE OF URBAN MANAGEMENT INSTITUTIONS IN THE DEVELOPMENT OF CITIES (CASE STUDY: PARS ABAD CITY)
}

\author{
Gholam Reza Mirie ${ }^{1}$ \\ Mohsen Sadeghi ${ }^{2}$
}

\begin{abstract}
The purpose of the present city of Parsabad. While the responsibility study was to determine the performance of responsible organizations in urban affairs administration as an important factor in the development of the city of Pars Abad. The statistical population of this research includes inhabitants of Parasabad city and managers and experts of urban affairs in 1396. The method of of the responsible authority in affairs of the city is not significantly related to the development of the employment and business environment and the establishment of effective communication channels with citizens and the development of popular participation
\end{abstract} this study is descriptive-practical study. For data collection, library and field method is used for urban data and questionnaire. These data are analyzed using SPSS software and also used to test the hypothesis of T-test. The results of this study show that the performance of the responsible unit in the affairs of the city has a significant relationship with the management and organization of the physical-space development process, equipping the service space and organizing facilities and facilities in the

Keywords: Urban Management, Urban Development, Urban Development, Physical Development, Parsabad.

\section{1- Statement of the Problem}

If a city is to be regarded as an organization, it must be at the top of it an element of future planning and current affairs management. This element can be called the city management (Saeednia, 2010: 21). Urban management is a large

\footnotetext{
${ }^{1}$ Assistant Professor of Geography and Urban Planning, Islamic Azad University, Zahedan Unit, Zahedan, Iran.*Corresponding Author Emaill:Gholam_Reza_Miri@yahoo.com.

${ }^{2}$ Ph.D. student of Geography and Urban Planning, Islamic Azad University, Chabahar Branch, Chabahar, Iran
} 
organization of effective and relevant official and non-official elements in various social, economic and physical aspects of urban life with the aim of managing, directing and controlling the comprehensive and sustainable development of the city. At present, the most important management challenges Urban in Third World countries is a response to urban inequalities and the emergence of political, social, economic, cultural and urban rights issues (Najati Hosseini, 2010: 6).

Present value of existing organizations and institutions plays a role in city management, which are categorized into four categories according to the administrativeexecutive and impact status: 1 . Organizations and central authorities of the national and regional authorities, including their provincial ministries and institutions. 2. Organizations and institutions, government The general and independent regions of the country. 3 . Private and unorganized organizations and organizations. 4. Elected organizations and elements of citizens' interests. (Saeedi Rezvani, Kazemian, 2012: 121). Therefore, in the current situation, we can not recognize councils or municipalities as the only city management institution, and we are confronted with a set of institutions of urban management in different parts of the city. Parsabad city is located in the northeastern part of Moghan plain in the west of the Caspian Sea. Due to its history and history, its formation as a city point is more youthful than all cities of Ardebil province. The rapid growth of population and development of Parsabad city has made it possible nowadays The opinion of the population and extent of the second city of the province after the city of Ardabil.

Development of the city of Parsabad has been positively and negatively affected by the role of urban management institutions. Positive influences means the proper implementation of urban development plans in accordance with the rules and regulations for implementing city planning and systematic guidance, which has led to the formation of Bakery neighborhoods, cultural figures, Pars Township, Fajr Township. The negative impact institutions, urban management, mostly because of a lack of communication between the part of institutions with each other and lack of communication consistent with the mayor, the shortage of specialists in 
organizations Andar work in the city and allocation of appropriate tasks between authorities, has led to the development of undesirable Horizontal shows a picture of the current issues. In this regard, the formation of the following neighborhoods Nhrtrab, freedom, liberty, sacrifice and expensive integration of surrounding villages, including: Mohammad Rezalv, Buick Khanlou, Ajirlu, Agdam, Rblv can be cited. The subjects identified in this study, the role of institutions involved in the urban development of the city are analyzed and in fact in this research is that while the root causes of the turmoil physical structure and promoting the development of Parsabad the The role of responsible departments in the development of urban affairs in the development of Parsabad city.

\section{Research Objectives}

1. Identify the performance of the responsible authorities in the administration of urban affairs as an important factor in urban development

2. Understanding the Impact of Urban Management Institutions on the
Physical-Spatial
Development
Parsabad City

390

3. To conduct a university research to identify and analyze one of the factors influencing urban development

4- Providing basic solutions for strengthening the performance of urban management institutions in the development of Parsabad city

\section{3- Research Questions}

1. Is the performance of the responsible organizations in the city administration affiliated with the management and organization of the city's physical-spatial development process?

2. Do the functions of the responsible authorities in the city administration have a significant relationship with the provision of space services and the organization of urban facilities?

3. Do the functions of the responsible authorities in the city administration have a significant relationship with the development of business and employment space?

4. Is the performance of the responsible authorities in the city administration affiliated with the effective communication channels of citizens and 


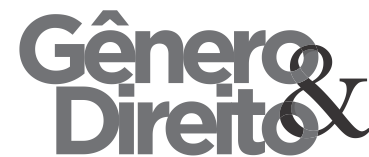

Periódico do Núcleo de Estudos e Pesquisas sobre Gênero e Direito

Centro de Ciências Jurídicas - Universidade Federal da Paraíba

V. 8 - $\mathrm{N}^{\circ} 03$ - Ano 2019

ISSN | 2179-7137 | http://periodicos.ufpb.br/ojs2/index.php/ged/index

the development of popular participation?

\section{Research Hypotheses}

1- The performance of the responsible organizations in the city administration has a significant relationship with the management and organization of the city's physical-spatial development process.

2. The functions of the responsible authorities in the administration of city affairs have a meaningful relationship with the provision of space services and the organization of urban facilities.

3. The performance of the responsible authorities in the affairs of the city has a significant relationship with the development of the work space and business.

4. The performance of the responsible authorities in the administration of city affairs has a significant relationship with the effective communication channels of citizens and the development of popular participation.

\section{Research Background}

Rahimi and Vahidigar (2011) have investigated the role of urban

391

management institutions in sustainable management in Tehran. Consequently, sustainable development, including the balanced growth and development of the economy, the environment and the human society and culture, is a complex task and the achievement of the importance of institutions It emphasizes the state through its legal powers and its responsibility to protect what is in the public domain. One of the decisionmaking and influential institutions for sustainable urban development is the Article 5 of the Ministry of Housing and Urban Development, which, according to the law, is the sole authority to change the comprehensive plan detailed in the city and determine the intended use of the landlord.

In the Technical Research and Others (2016), entitled The Role of Urban Tourism Management in the Development of Tourism (Case Study: Turin City), it was found that cities like Bogota, Colombia, have good potential for tourism development, but due to weaknesses in urban management, the lack of management integrity In the sustainable exploitation of attractions, the lack of access and information facilities, the lack of coordination and co-ordination among various urban 
institutions, the inability to provide sanitation and urban cleaning and land use planning problems, the tourism sector not only distanced from sustainable development but also Negative passes.

Aghajani (2016) studied the role of urban management in spatial development in spite of urban management efforts in Isfahan in solving various urban problems of the city. Therefore, in order to solve these problems, the management of the city requires a more detailed and comprehensive planning, which involves all aspects of the city.

\section{Theoretical Foundations of the}

\section{Research}

The urban management system is responsible for the management and management of all geographical space and urban functions, and in this regard, all relevant elements and organizations and the whole city area must be monitored and controlled. The data of the urban management system are the demands of the government and the citizens, and their achievements, which are achieved through a process of planning, design and implementation, are the development of the quality and quality of urban life (Nejati Hosseini, 2010: 108).

Urban management is to organize factors and resources to meet the needs of the city's residents. Given this city, it has a military presence, urban management is more than the city's physical surroundings (Metropolitan,2010:76). The general purpose of the urban management system is a broad organization consisting of official elements and other formal elements, effective and relevant in various aspects of the social, economic, and physical life of the city, with the aim of managing, directing and controlling the comprehensive and sustainable development of the relevant city (Najati Hosseini , 1389: 106). Urban management in the turning point to the concept and nature of management should include the mechanism of planning, organization, guidance, control and coordination in the administration of city affairs, whose goals are to be integrated in the city's comprehensive development and improvement of the level of welfare and comfort of citizens.. It is clear that realizing this goal can be achieved by 
effectively and efficiently utilizing both material and human resources.

Considering that the structure and nature of the city are shaped in the form of a system composed of various components of the physical, social, economic, demographic, cultural, commercial, transportation, etc., the nature of the diverse urban space can be found in the interactions of space A city of commercial space, social space, business environment, activity, investment climate, cultural space, etc. (Bastie, 2015: 17), which has a systemic nature and requires systematic approach and management. Therefore, the definition of urban management is far more extensive than the organizational and executive bodies of the municipality and city councils. It is imperative that the municipality and city of the city as the main core of urban management, in addition to its inter-organizational coherence within its organization, have an active coordination with external factors. An organization is involved in the administration of city affairs (Ghafari Galeedeh, 2015: 213-214). The following figure illustrates the role of self-employed drivers in urban management.

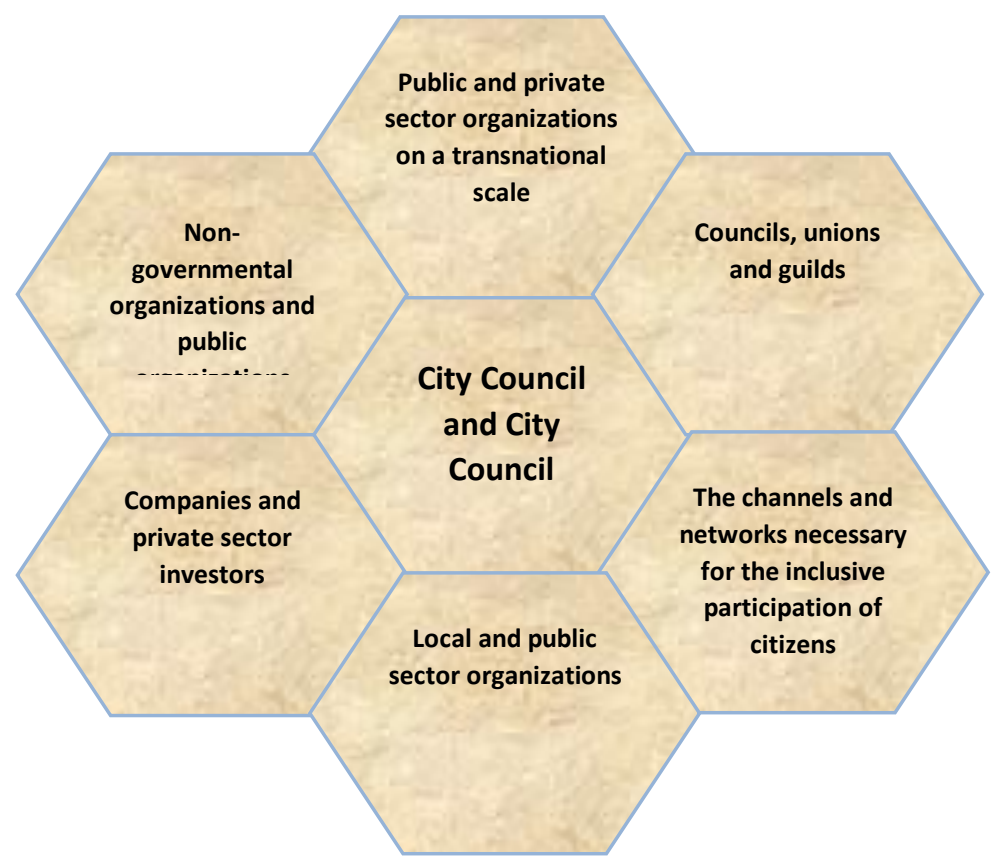

Figure (1) Managing agents in Urban Management 
In the development of cities, several factors are involved, one of which is the urban management system. In this system, the role of urban management bodies and institutions or individuals and groups (regional and local) and the impact of their decisions on urban development can be considered. These decision-makers and policymakers have played a role in urban development, in which we focus on the role of urban management in urban development.

\section{Improvement of human} settlements and public services development, comprehensive and sustainable development of urban environment, urban planning, how to deal with urban issues and rational direction of the city, organizing factors and resources for responding to the needs of residents of the city, controlling the city's physical development and development, and Carrying out the necessary plans for the future development of the city, securing public interest, respecting the rights of citizens, the demands and demands of citizens, adjusting and regulating the land and its storage for the future expansion of the city, taking into account the provision of sustainable development, social justice and public benefit In the process of spreading cities, balancing the interests of various forces and conflicting groups Social protection, maintenance and improvement of the physical environment of cities, urban environment, city safety, urban transport, urban quality and urban development, and the demands of the government and citizens, the implementation of major urban projects, the proposal or the creation of a change in the Commission of the matter Five, creation or increase of use, such as administrative, medical, military, police, and other utilities, issuing mortgages from municipalities, land plots and land ownership, implementation of massive projects, municipality revenue from sources such as licenses Construction, Density and Separation of Land, Renovation, Parking, Balcony, and Walking, etc.

\section{Introduction of the realm of research}

Parsabad city is located at 47 degrees 54 minutes east longitude and 39 degrees and 39 minutes north latitude 
with an average elevation of 44 meters above sea level. The total population of the city is 180,456 (Statistical Yearbook, 1395). A plain town that is located on the alluvial deposits of the Aras River, with a very small slope from the southwest to the northeast. The development of the city on the southern edge of the river of Aras prevented the development of the city in its northern direction, and inevitably the urban development process has taken place in the best agricultural lands of the southern margins, southwest and southeast of the city. Has a second municipality district and seven people are citizens of the Islamic Republic, and then the city is the second most populous city in the province.

\section{Statistical population and sample size estimation method}

The statistical community to which the statistical population also refers to the collection of people (or elements) has common characteristics that are being investigated (Ezati, 2014: 128). In this research, the unit analysis includes the city of Pars Abad and its development, and the statistical society of the research is conducted by the relevant experts in the management of housing and urban planning, government and service departments, and so on. The information required for obtaining senior, middle and operational managers 'and experts' opinions will be dealt with. The sample size is calculated using the formula $n=\frac{z^{2} p q}{d^{2}}$ of 100 people.

\section{Information Collection Methods}

In this research, two methods of library (checking of books, journals, etc.) and fieldwork (survey using questionnaire technique) were used to gather information.

\section{Data and information analysis methods}

The SPSS software is used to analyze and test hypotheses. The test used in this research is T-test.

\section{Research findings}

- Descriptive statistics

- $94 \%$ of the questionnaires are male and $6 \%$ of them are women.

- 41 people, $41 \%$ of the age group of 20-40 years old, 59 (59\%) in the age group of 40 to 65 years old, and two groups of less than 
20 years of age and 65 years of age are not included in this group. Which is shown in the figure below.

- 11 people, $11 \%$ have a master's degree and a doctorate, 49 are $49 \%$, have a bachelor's degree, 32 are $32 \%$ have an associate degree, and 8 are $8 \%$ have a diploma. Accordingly, the highest percentage of

\section{6}

respondents with a bachelor's degree.

\section{2- Examination of assumptions}

Testing the First Hypothesis: The performance of the responsible authority in city affairs administration has a significant relationship with the direction and organization of the city's physical-spatial development process.

Table (1) Test Table The first hypothesis

\begin{tabular}{|c|c|c|c|c|c|}
\hline Error & $\begin{array}{c}\text { Degree of } \\
\text { Freedom of } \\
\text { Error }\end{array}$ & Score t & $\begin{array}{c}\text { Standard } \\
\text { deviation }\end{array}$ & Average & Number \\
\hline 0.000 & 99 & 44.5 & 7.5 & 33.8 & 100 \\
\hline
\end{tabular}

Considering that the significance level of the test in the examination of the above hypothesis is less than standard. Therefore, the test is meaningful, that is, the function of the responsible authority in the administration of city affairs has a significant relationship with the direction and organization of the urbanspatial development process of the city. As a result, the first hypothesis is confirmed. The $\mathrm{t}$ test score is 44.5 and the standard deviation is 7.5 and the mean of the group is 33.8. According to the results and test of the first hypothesis, the elements of urban governance and management at the local and regional level, such as municipality, governorate, governorate, housing and urban organization, city council, etc., all contribute to the development of the city's physical-spatial Parsabad played a role. Therefore, the development, guidance and organization of the physical and physical development of the city of Parsabad has been largely dependent on the performance and demands of its responsible authorities, 
and in particular the municipality as local institutions, which plays a more important role in the spatial development of Parsabad city than other factors.

Testing the second hypothesis:

The performance of the responsible authorities in the city administration has a significant relationship with the provision of space services and the organization of urban facilities.

Table(2) Testing the second hypothesis

\begin{tabular}{|c|c|c|c|c|c|}
\hline Error & $\begin{array}{c}\text { Degree of } \\
\text { Freedom of } \\
\text { Error }\end{array}$ & Score t & $\begin{array}{c}\text { Standard } \\
\text { deviation }\end{array}$ & Average & Number \\
\hline 0.000 & 99 & 46.6 & 3.1 & 14.5 & 100 \\
\hline
\end{tabular}

Considering that the significance level of the test in the examination of the above hypothesis is less than standard, so the test is significant. That is, the operation of the responsible authorities in the administration of city affairs has a significant relationship with the provision of space services and the organization of urban facilities and facilities. As a result, the second hypothesis is also confirmed. The test score is 46.6 and the standard deviation is 3.1 and the mean of group is 14.5. Based on the results and testing of the second hypothesis, official institutions and other official municipal administration at the local and regional level, such as the governorate, the governorate, the housing and urban organization, the municipality, the city council, and the media service, expand the equipping of service space and organization Urban facilities and facilities played a role in Parsabad. Therefore, the expansion, equipping and organization of urban facilities and facilities of the public services of Parsabad largely depends on the performance and demands of the responsible authorities in the management of the city of Parsabad.

Testing the Third Hypothesis: The performance of the responsible authorities in the affairs of the city has a significant relationship with the 
development of the space of employment

and business.

Table(3) Testing the third hypothesis

\begin{tabular}{|c|c|c|c|c|c|}
\hline Error & $\begin{array}{c}\text { Degree of } \\
\text { Freedom of } \\
\text { Error }\end{array}$ & Score t & $\begin{array}{c}\text { Standard } \\
\text { deviation }\end{array}$ & Average & Number \\
\hline 0.30 & 99 & 24.3 & 1.2 & 2.9 & 100 \\
\hline
\end{tabular}

Based on the results of the $\mathrm{T}$ test, which is presented in Table 4-3, and considering that the significance level of the test in the above hypothesis is higher than the standard, so the test is not significant. That is, the performance of the responsible organizations in the affairs of the city is not significantly related to the development of the space of employment and business. This shows that the operation of the responsible authority does not affect the prosperity and development of the work space and business in the city of Parsabad. As a result, the hypothesis Third is not approved. The $\mathrm{T}$ test score is 24.2 and the standard deviation is 1.2 and the mean of the group is 2.9 .

Testing the fourth hypothesis: The performance of the responsible authorities in the affairs of the city has a meaningful relationship with the effective communication channels of citizens and the development of popular participation.

Table (4) Testing the fourth hypothesis

\begin{tabular}{|c|c|c|c|c|c|}
\hline Error & $\begin{array}{c}\text { Degree of } \\
\text { Freedom of } \\
\text { Error }\end{array}$ & Score t & $\begin{array}{c}\text { Standard } \\
\text { deviation }\end{array}$ & Average & Number \\
\hline 0.30 & 99 & 24.3 & 1.2 & 2.9 & 100 \\
\hline
\end{tabular}

Based on the results and the results of the T-test, which is presented in Table 4-4, and considering that the significance level of the test in examining the above hypothesis is higher than the standard level, so the test is not significant, that is, the function of the responsible authority in the affairs of 
the city in relation There is no meaningful way to create effective communication channels for citizens and to expand popular participation. As a result, the fourth hypothesis is not confirmed. The T test score is 27.22 and the standard deviation is 2.7 and the average is 5.6.

\section{Conclusion}

There are several factors involved in the development and development of cities, one of which is the urban management system. In this system, the role and elements of urban management, or individuals and groups of influence (at the regional and local level) and the impact of their decisions on the development and development of the city can be considered. Accordingly, considering the various factors affecting the development of a single vision for All cities and the acceptance of a particular factor in the development of cities can not be effective. Therefore, considering the role of all the effective factors and integrating with other factors, we must investigate the role of the set of effective factors in the development of the city. However, in this research only the role of the responsible organizations in the development of the city has been paid more attention.

As in the first hypothesis, as well as the documents obtained by the municipality regarding the issuance of a building permit from 2003 to 2010 indicating the rising trend of the license, the expansion of construction and management of the standardization and the organization of the physical-spacebased urbanization During these years. However, the weakness of the specialist forces in the areas related to the physicalspatial development of the city of Parsabad should not be ignored, which has led to the expansion of illegal construction horizontally in the surrounding lands often in the informal settlement (marginalization) in Parsabad.

Regarding the second hypothesis, in spite of the fact that the urban experts and managers consider the role and functions of the responsible organizations in the spatial equipments of service and organization of facilities and equipment in a meaningful relationship. If the lack of interdisciplinary communication between the institutions in the city affairs and the lack of coherent communication with the municipality and interactions, 
the results have been very unsatisfactory for the city of Parsabad.

Regarding the third and fourth hypotheses, based on the results of the responses of experts and urban managers who consider the actions of the responsible authorities in city affairs in developing the business and employment environment, as well as in creating effective channels of communication with citizens and promoting popular participation. If the elements (formal and informal), according to the community base, as well as the use of the most effective tools of urban management, namely, urban laws and regulations, could act in a way that could have a significant effect on the effective communication channels with citizens and the expansion of public participation. To develop the business and employment space in the city.

Therefore, the way of expansion and development of the city of Parsabad has been largely influenced by the forces and processes of the abovementioned management. However, considering that urban development plans (comprehensive and detailed) and geographic factors also extend the city to the south, south-east and south Western sources, it can be concluded that the responsible managers in the management of the affairs of the city of Parsabad have played a leading role in the development and expansion of the city. Therefore, it can be said that Parsabad municipalities facilitate the effects of other factors on urban development.

\section{Suggestions}

Regarding the past topics, the field information collected, the test of the hypotheses and its results, to strengthen the performance of the institutions of urban management in the development of the city of Parsabad, we will present the basic solutions.

1. Strengthening the interinstitutional relationship and coherent communication with the municipality; a). Supervising the responsible authorities in city affairs, especially the municipality, on buying and selling the suburbs; b). Selecting specialized meetings between the responsible institutions, the private sector, City people to invest and build mutual trust and provide solutions to improve the performance of the responsible authorities in the affairs of the city of Parsabad. 
2. Strengthening the staffing capacity (quantitatively and qualitatively) of the responsible institutions in areas related to physicalspace development (building police, licensing of buildings, etc.).

3. Organizing meetings and justification classes based on the presentation of goals and the need for a comprehensive plan for managers and staff of the institutions associated with the plan.

4. Familiarity of managers and practitioners in urban affairs with practical urban. planning and urban management techniques.

5. Strengthening municipal finance by providing practical solutions to prevent the sale. of congestion and waiver of construction violations.

6. Use of creative forces specializing in organizations involved in urban affairs.

7. Gaining citizens' trust through active citizenship.

8. Improvement and expansion of the quantitative and qualitative urban furniture.

9. Preparation and development of the program according to the needs of the city.
10. Avoid horizontal extension with vertical expansion plan.

References:

Bastie, Jean and Bernard Sez, 2015, City, Translated by Ali Ashrafi, Tehran: University of Art Publishing Statistical Yearbook of Ardabil Province, 2015.

Saeednia, Ahmad, 2010, Green Book Collection of Municipalities, Urban Management, Vol. 11, Publications of the Organization of Municipalities of Iran.

Sarafi, Mozaffar and others, 2010, The concept, bases and challenges of urban management, Urban Management Quarterly, Year 1, No. 2.

Ezzati, Morteza, 2016, Research in Social Science, Tehran: Nour-e-Elam Publication, Second Edition.

Ghafari Galeedeh, Ata, 2015, Organization of the city's business system and presentation of a suitable model, Thesis of Ph.D. in Geography and Urban Planning, Tarbiat Modares University of Tehran. 
Saeedi Rezvani, Kazemian, Gholamreza,

2012, Feasibility of Transferring New

Tasks to Municipalities, Volume Four,

Tehran: Publications of Municipality,

First Edition.

Nejati Hosseini, 2010, Seyyed

Mahmood, Urban Planning and

Management: Empirical Issues and

Challenges, Tehran: Publications of the

Organization of Municipalities, Second

Edition. 